\title{
Lymphocyte subsets in the small intestine of piglets fed with probiotic and zinc: a qualitative and quantitative micro-anatomical study
}

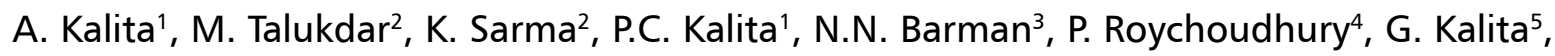 \\ O.P. Choudhary ${ }^{1}{ }^{10}$, P.J. Doley' ${ }^{1}$, S. Debroy ${ }^{1}$, K. Keneisenuo ${ }^{1}$, R. Sarkar ${ }^{1}$ \\ ${ }^{1}$ Department of Veterinary Anatomy and Histology, College of Veterinary Sciences and Animal Husbandry, \\ Central Agricultural University (I), Selesih, Aizawl, Mizoram, India \\ ${ }^{2}$ Department of Veterinary Anatomy and Histology, College of Veterinary Science, Assam Agricultural University, \\ Khanapara, Guwahati, Assam, India \\ ${ }^{3}$ Department of Veterinary Microbiology, College of Veterinary Science, Assam Agricultural University, Khanapara, \\ Guwahati, Assam, Indi \\ ${ }^{4}$ Department of Veterinary Microbiology, College of Veterinary Sciences and Animal Husbandry, Central Agricultural \\ University (I), Selesih, Aizawl, Mizoram, India \\ ${ }^{5}$ Department of Livestock Production and Management, College of Veterinary Sciences and Animal Husbandry, \\ Central Agricultural University (I), Selesih, Aizawl, Mizoram, India
}

[Received: 20 September 2020; Accepted: 7 December July 2020; Early publication date: 30 December 2020]

Background: Piglet mortality is a real concern to the pig farmers. The major cause is due to the late maturation of the immune system and dietary changes in postweaned piglets. The potential role of probiotic and zinc in the stimulation of the immune system is well established. Hence, the present study was undertaken to evaluate alterations of $T$ and $B$ cells in the small intestine after dietary inclusion of probiotic and zinc in pre and post-weaned piglets.

Materials and methods: A total of 18 healthy Large White Yorkshire (LWY) piglets, irrespective of sex obtained from 3 litters at the age-group of 20, 30 and 60 days. They were divided into a control group fed with basal diet and a treatment group fed with probiotic and zinc supplement along with the basal diet, consisting of three animals in each group. The piglets were weaned at 28 days of age. After sacrificing the animals at day 20,30 and 60 from both the groups, the abdominal cavity was opened and small intestinal tissue samples were collected, processed and stained by indirect immunofluorescence technique. The slides were evaluated under the fluorescent light microscope. The data were statistically analysed.

Results: The different $T$ and $B$ cell subsets were recorded in the lining epithelium, core of villus, crypt area of lamina propria and Peyer's patch area. The number of $\mathrm{CD}^{+}, \mathrm{CD}^{+}, \lg \mathrm{A}^{+}$and $\lg \mathrm{M}^{+}$cells was higher in the treated piglets than the control group of animals, irrespective of segments of intestine and age-group. Conclusions: It can be concluded that the dietary supplementation of probiotic and zinc was found to be good additives as they can stimulate the immune response in piglets, especially during the critical early post-weaning period. (Folia Morphol 2022; 81, 1: 82-90)

Key words: probiotic, zinc, lymphocyte, small intestine, piglet

Address for correspondence: Dr. O.P. Choudhary, Department of Veterinary Anatomy and Histology, College of Veterinary Sciences and Animal Husbandry, Central Agricultural University (I), Selesih, Aizawl, Mizoram-796015, India, tel: 91-9928099090, e-mail: dr.om.choudhary@gmail.com This article is available in open access under Creative Common Attribution-Non-Commercial-No Derivatives 4.0 International (CC BY-NC-ND 4.0) license, allowing to download articles and share them with others as long as they credit the authors and the publisher, but without permission to change them in any way or use them commercially. 


\section{INTRODUCTION}

Pre-weaning piglet mortality ranges from $5 \%$ to $35 \%$, which causes major economic issues in pig production [18]. Similarly, weaning is a critical stage in pig production because the piglets have to face many challenges such as low feed intake, acute diarrhoea and body weight loss, which causes nutritional, immunological and psychological disruptions [15]. The innate immune cells and gut-associated lymphoid tissue are not functionally developed until 4-7 weeks of age [9]. Diet plays an important role in the maturation and modification of the gut-associated immune system and the development of gut function [5]. Probiotics particularly lactic acid bacteria have beneficial effects on the health of the host [20]. These probiotics bacteria can able to induce natural and acquired immunity in healthy mice [10]. The beneficial effect of probiotics in respect of immunity was also recorded in sows and piglets [22]. In addition, zinc supplementation has been responsible for maintaining nonspecific defence mechanisms [21]. Kalita et al. [14] already described the probiotic and zinc effects on the small intestinal mucosal cells in piglets.

In this communication, we assessed the effects of probiotic and zinc supplementation in pre- and post-weaned piglets on the qualitative and quantitative development of the gut-associated immune system by the use of the indirect immunofluorescence technique. The objective of the present study was to examine the effect of feeding probiotic (Lactobacillus acidophilus, Lactobacillus rhamnosus and Bifidobacterium longum) and zinc on $T$ and $B$ cells subsets that demonstrate the immune status in the small intestine of critical pre and post-weaned piglets.

\section{MATERIALS AND METHODS}

The present study was conducted in the pig farm of the College, Central Agricultural University (I), Mizoram, India. The Institutional Animal Ethics Committee ethically approved the animals used for the experiment. The experiment was carried out from February, 2017 to May, 2019.

\section{Animals}

The present study was conducted on eighteen healthy Large White Yorkshire (LWY) piglets, irrespective of sex at different stages of development as agegroup of 20, 30 and 60 days. Each of six numbers of these piglets was selected from three sows. The piglets were divided into control group (C) fed with basal diet and treatment group ( $\mathrm{T}$ ) fed with combined probiotic and zinc oral supplement along with the basal diet. The basal diet used in this experiment was in pellet form and formulated to provide the nutrient requirements as per National Research Council (NRC) [19]. The piglets were weaned at 28 days of age.

\section{Selection, dose and period of treatment}

A mixture of probiotic bacteria consisted of Lactobacillus acidophilus $\left(0.65 \times 10^{9}\right)$, Lactobacillus rhamnosus $\left(0.4 \times 10^{9}\right)$ and Bifidobacterium longum $\left(0.2 \times 10^{9}\right)$ reconstituted in $1 \mathrm{~mL}$ of normal saline solution, were orally administered to each treatment group of piglets individually from birth to 10 days, so that each animal received probiotic mixture at a final concentration of $1.25 \times 10^{9}$ colony forming unit/day [17]. The $\mathrm{ZnO}$ was given orally to the treatment group of piglets at the rate of $2000 \mathrm{ppm} /$ day from birth to 10 days of age [4]. The piglets of the control group were given the same volume of sterilised saline solution.

\section{Sample preparation}

The experimental animals were anesthetised using diazepam at the rate of $2 \mathrm{mg} / \mathrm{kg}$ body weight followed by ketamine at the rate of $10 \mathrm{mg} / \mathrm{kg}$ body weight intravenously in the peripheral ear vein and then exsanguinated the animals. The animals were sacrificed on days 20, 30 and 60 from both the groups. After sacrifice, the animal's abdominal cavity was exposed, and parts of the small intestine were dissected out [12]. Tissue samples were taken immediately after sacrifice from the duodenum $(5 \mathrm{~cm}$ caudal to the pylorus), jejunum (in the middle of the jejunum) and ileum ( $5 \mathrm{~cm}$ cranial to the ileocaecal valve).

\section{Monoclonal antibodies}

The murine monoclonal antibodies (mAbs) reactive with porcine leukocyte surface molecules, i.e., cluster of differentiation (CD) antigens or immunoglobulin A (IgA) molecule on plasma cells, used as the primary antibodies (pAbs) to study in situ identification, distribution and quantification patterns of respective lymphoid and non-lymphoid cell subsets residing small intestine of experimental piglets are listed in Table 1.

\section{Immunofluorescence}

Different cell populations of the immune system were identified by indirect immunofluorescence (Indi- 
Table 1. List of primary antibodies and secondary antibody conjugates (conjugated with FITC) used for immunofluorescence identification/localisation and morphometric quantification of $T$ and $B$ cell subsets in the small intestine

\begin{tabular}{|c|c|c|c|c|c|}
\hline Antibody & Isotype & Antibody specificity & Cytochrome & Target cells/Molecules & Origin \\
\hline \multicolumn{6}{|l|}{ Primary } \\
\hline MIL 17 & $\lg G 2 b$ & $\operatorname{CD} 4 \alpha$ & None & Helper T lymphocytes & Bio-Rad Laboratories, USA \\
\hline MIL 12 & $\lg G 2 a$ & $\operatorname{CD} 8 \alpha$ & None & Cytotoxic T lymphocytes & Bio-Rad Laboratories, USA \\
\hline K61 1B4 & $\lg \mathrm{G} 1$ & $\lg A$ & None & $\lg \mathrm{A}^{+}$plasma cell & Bio-Rad Laboratories, USA \\
\hline K52 1C3 & $\lg \mathrm{G} 1$ & $\lg M$ & None & $\lg \mathrm{M}^{+}$plasma cell & Bio-Rad Laboratories, USA \\
\hline \multicolumn{6}{|l|}{ Secondary } \\
\hline Goat anti-mouse lgG- FITC & $\lg G$ & Mouse lgG & FITC & Mouse lgG & Sigma-Aldrich, USA \\
\hline
\end{tabular}

rect-IF) technique [22]. Briefly, small intestinal sections that had been cut to a thickness of $5 \mu \mathrm{m}$ were deparaffinised, dehydrated and hydrated to water. After antigen retrieval in sodium citrate buffer $(10 \mathrm{mM}, \mathrm{pH}$ 6.0), the nonspecific binding sites were blocked by $1 \%$ bovine serum albumin (30 min at room temperature). Then, sections were flooded with a primary monoclonal antibody (BIORAD, Table 1) at a dilution of 1:100 and incubated overnight $\left(4^{\circ} \mathrm{C}\right)$. Sections were washed 3 times (5-min each) with washing buffer (phosphate buffer saline mixed with $0.035 \%$ Tween 20 ) and stained with secondary antibody (anti-mouse IgG-FITC) conjugated with FITC (Sigma-Aldrich, Table 1) at a dilution of 1:200 for 60 minutes at room temperature. The excess secondary antibody was removed by washing the sections with a wash buffer 3 times for 5 minutes each. Finally, the sections were mounted with mounting media (glycerol). The immunostained slides were visualised and photographed under the fluorescent light microscope at $400 \times$ magnification (Olympus BX 51, Japan).

Cells counts of the sections were performed at 400-fold magnification. Histomorphometric analysis of targeted immunopositive cells was counted in 10 fields (representing a tissue area of about $0.24 \mathrm{~mm}^{2}$ ) from each of the three sampled piglets per group [24]. Such counting included villus epithelium, crypt epithelium, villus and crypt lamina propria, submucosa and Peyer's patches. Results were expressed as mean counts per unit area.

\section{Statistical analysis}

The data obtained were analysed using statistical package SPSS version 20. Differences in cell counts were accessed using the Student's t-test and differences between experimental groups by one-way ANOVA.

\section{RESULTS}

The distribution and number of $\mathrm{CD}^{+}, \mathrm{CD} 8^{+}, \lg \mathrm{A}^{+}$ and $\operatorname{lgM}^{+}$cells in the small intestine of control and treated piglets were analysed by indirect immunofluorescence technique.

\section{CD4+ lymphocytes}

The CD4+ $\mathrm{T}$ lymphocytes were located in the core of the villus (Fig. 1A), crypt area of the lamina propria (LP) (Fig. 1B) and Peyer's patch (PP) area (Fig. 1C) of the small intestine in both the group of piglets. However, these lymphocytes were concentrated in the core of the villus and crypt area of the LP in the duodenum as the PP were found to be absent in this segment of the intestine. The $\mathrm{CD}^{+}{ }^{+} \mathrm{T}$ lymphocytes were highly concentrated in the crypt area, followed by the PP area and the core of the villus (Fig. 1D). These lymphocytes were not observed in the epithelium. The total number of CD4 ${ }^{+} \mathrm{T}$ lymphocytes exhibited an increasing trend in LP and PP areas towards the higher age in both the groups. In the LP area of the current study, the number of cells expressing the CD4 co-receptor was increased significantly at day 60 ( $p<0.05)$ in the duodenum; at day 20 ( $p<0.01)$, day 30 ( $p<0.05)$ and day 60 ( $p<0.01)$ in jejunum; and day $30(p<0.01)$ and day $60(p<0.01)$ in the ileum of piglets fed with probiotic and zinc in compared to the control group of piglets (Fig. 2A). Similarly, in PP area of this study showed a significant increased $(p<0.01)$ in $C D 4^{+}$immunopositive cells at day 20 , day 30 and day 60 in the jejunum of treated piglets (Fig. 2B).

\section{CD8+ lymphocytes}

The immunopositive CD8 ${ }^{+}$cells were consistently present within the epithelium (Fig. 3A), the core of LP (Fig. 3B) and the crypt area (Fig. 3C) of the intestinal 

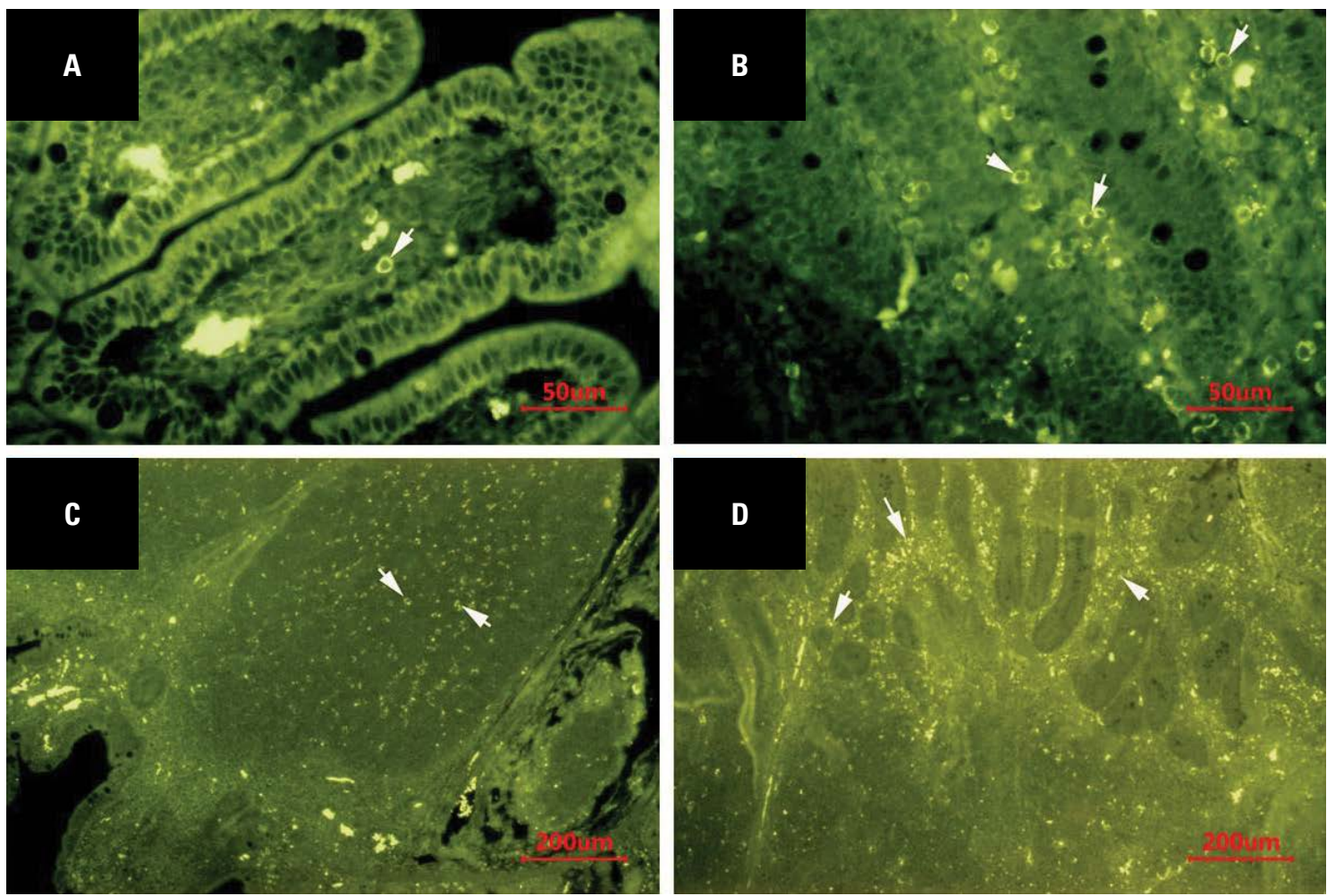

Figure 1. CD4 ${ }^{+}$T lymphocytes in 30-day-old treated piglets; A. Core of the villus (arrow) in duodenum; B. Crypt lamina propria area (arrow) of jejunum (Indirect-IF method, $\times 400$ ); C. Peyer's patch area (arrow) of ileum; D. Rich population (arrow) in the crypt area of ileum (Indirect-IF method, $\times 100)$.
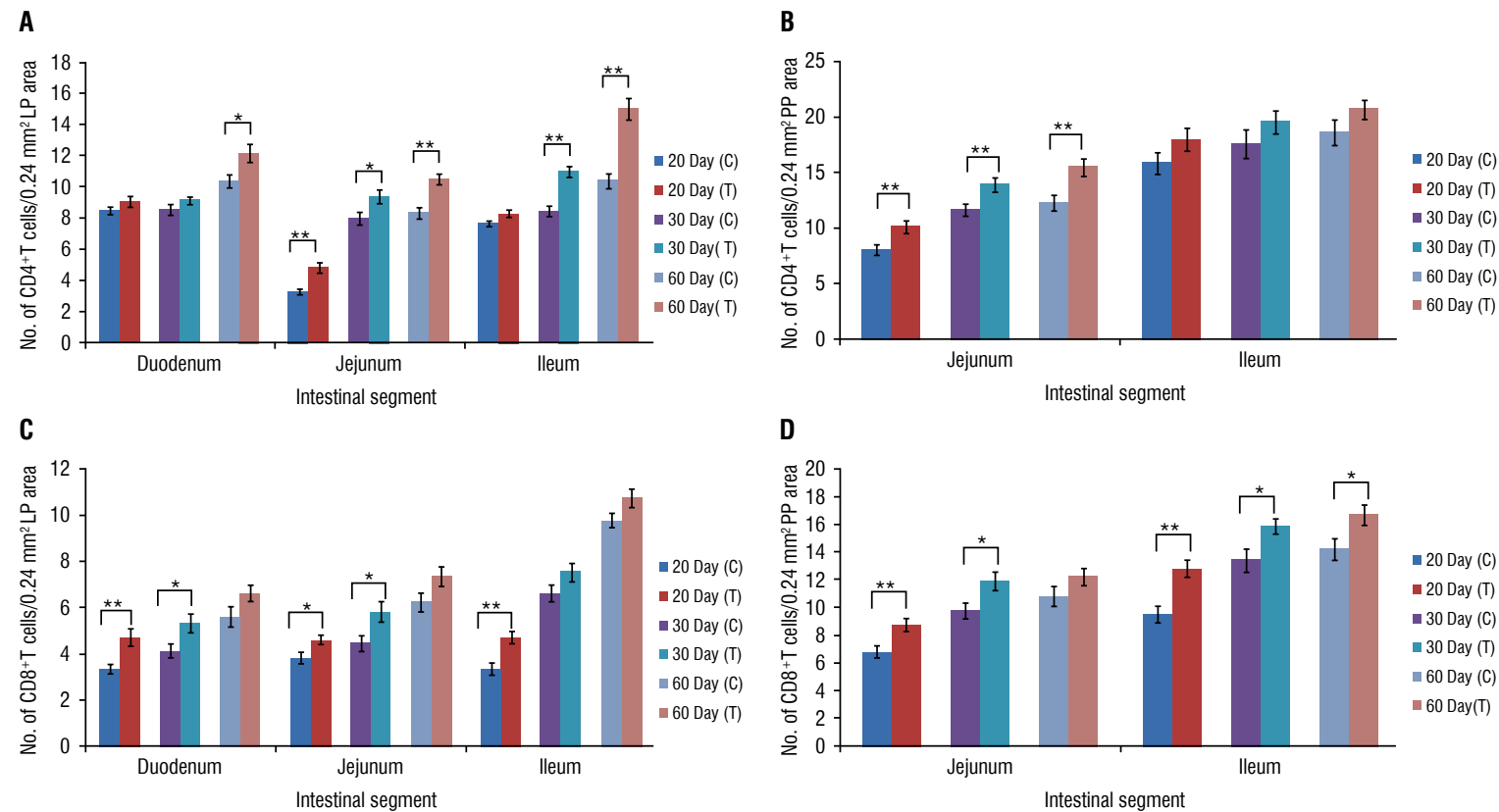

Figure 2. Localisation of T lymphocytes in the small intestine of control and treatment group of piglets $\left({ }^{*} p<0.05,{ }^{* *} p<0.01\right) ; \mathbf{A}, \mathbf{B}$. CD4 ${ }^{+}$ T lymphocytes in lamina propria (LP) and Peyer's patch (PP) area; C, D. CD8+ T lymphocytes in LP and PP area. 

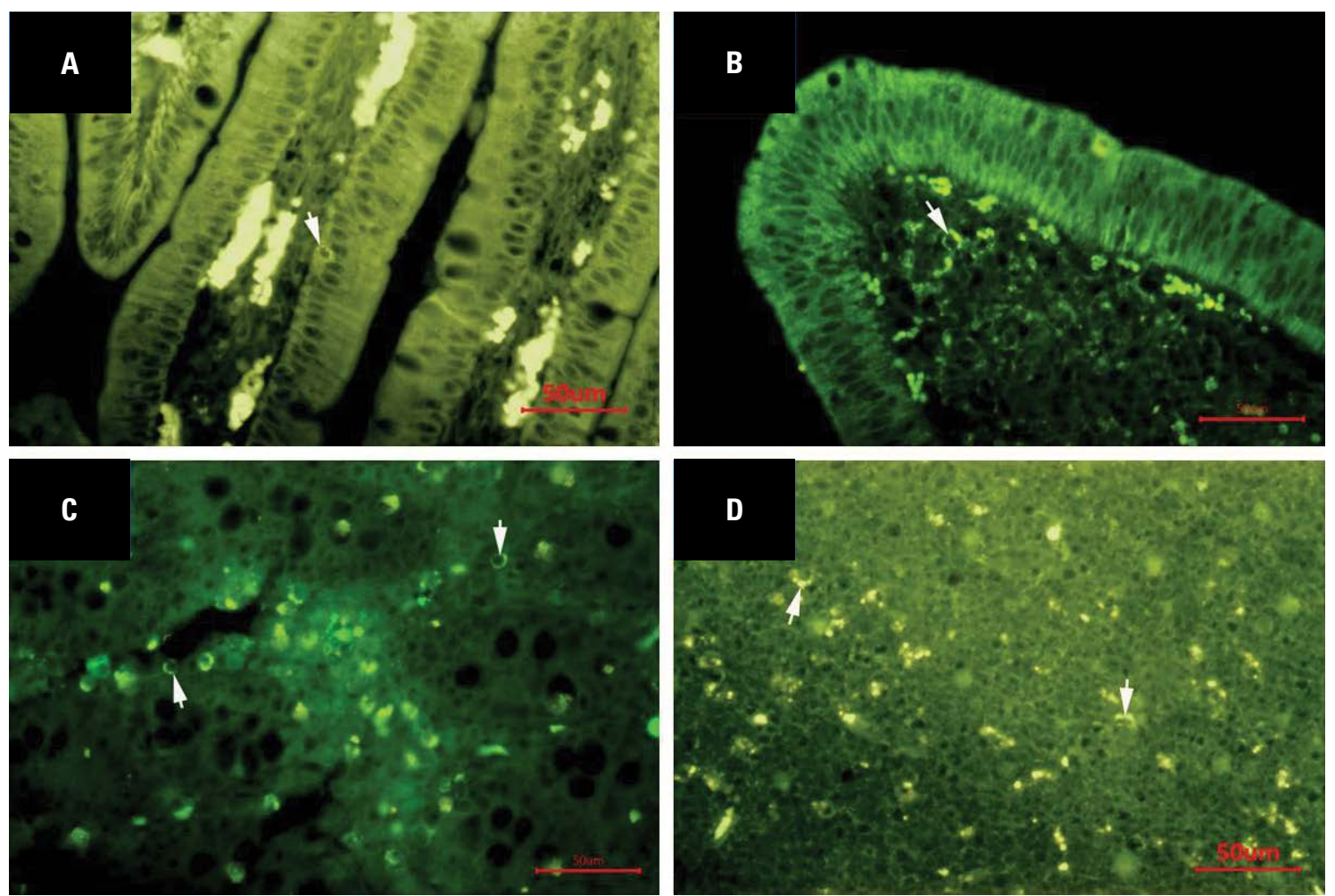

Figure 3. CD8 ${ }^{+}$T lymphocytes in 20-day-old treated piglets (Indirect-IF method, $\times 400$ ); A. Lining epithelium (arrow) of duodenum; B. Core of lamina propria area (arrow) in duodenum; C. Crypt area (arrow) of jejunum; D. Peyer's patch area (arrow) of ileum.
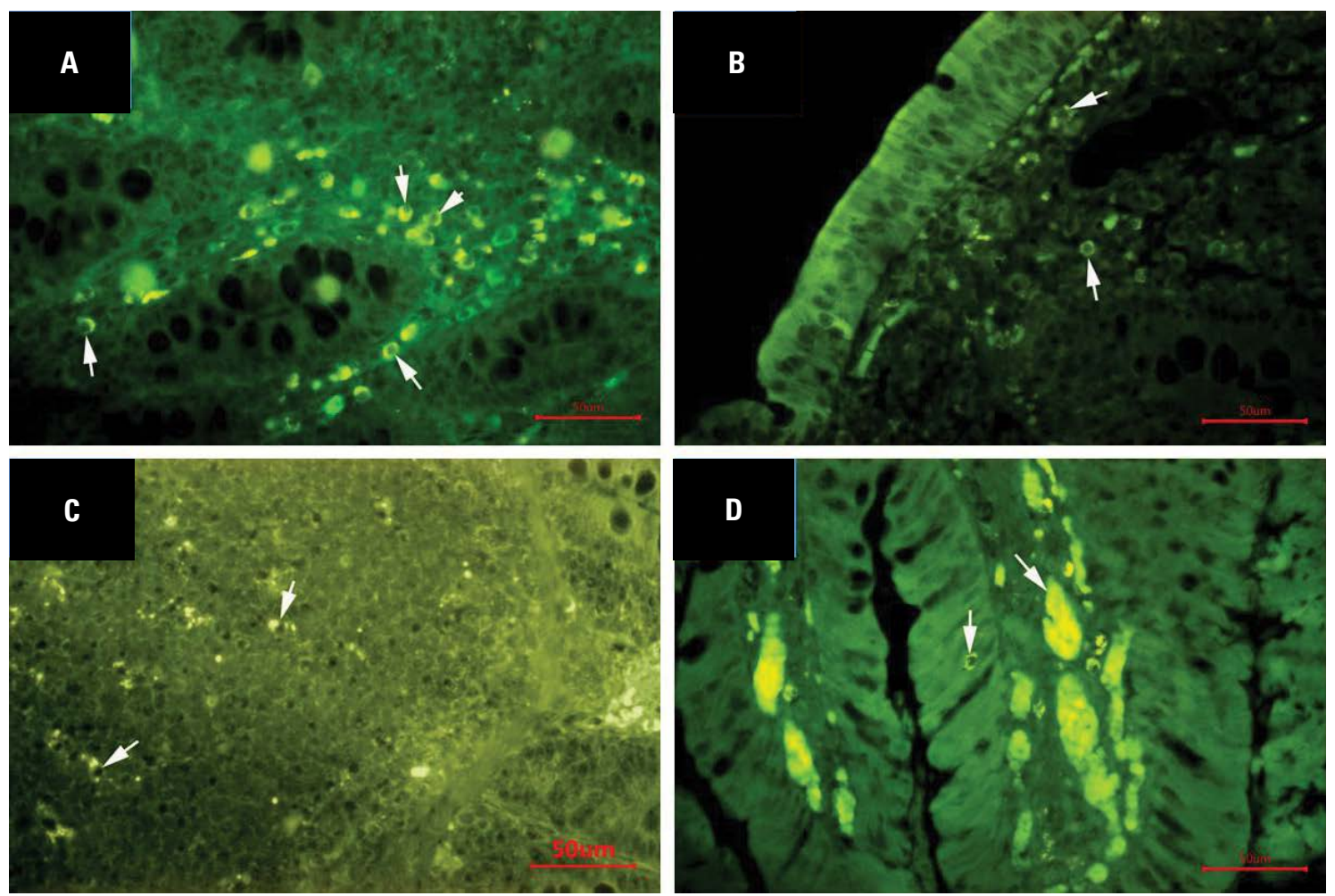

Figure 4. IgA+ B lymphocytes in 60-day-old treated piglets (Indirect-IF method, $\times 400$ ); A. Crypt area (arrow) of duodenum; B. Core of lamina propria (LP) area (arrow) in jejunum; C. Peyer's patch area of ileum; D. Lining epithelium and LP area along with their secretions (arrow) in jejunum. 
A

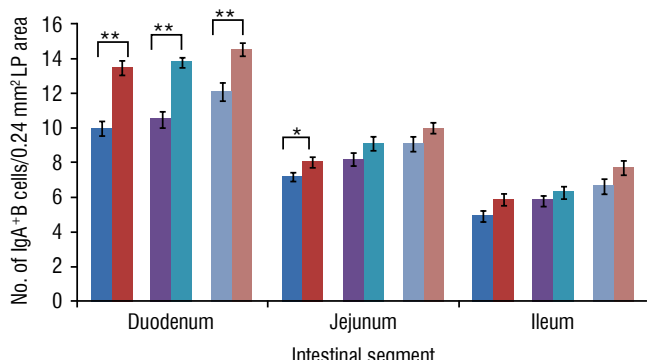

C

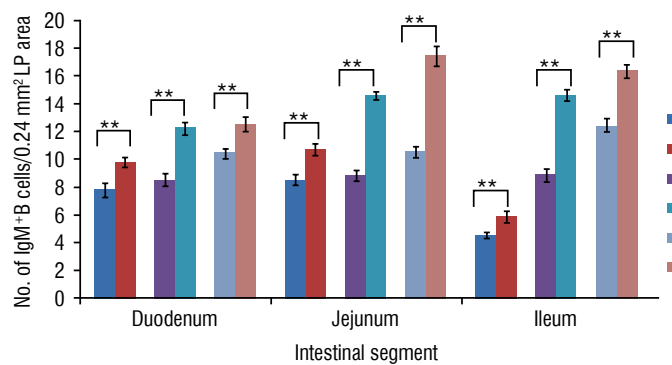

B

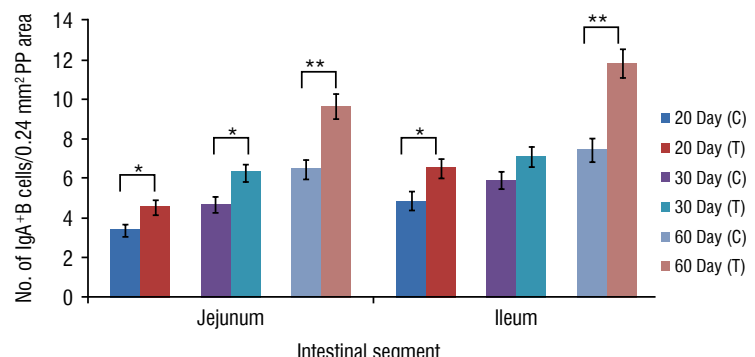

D

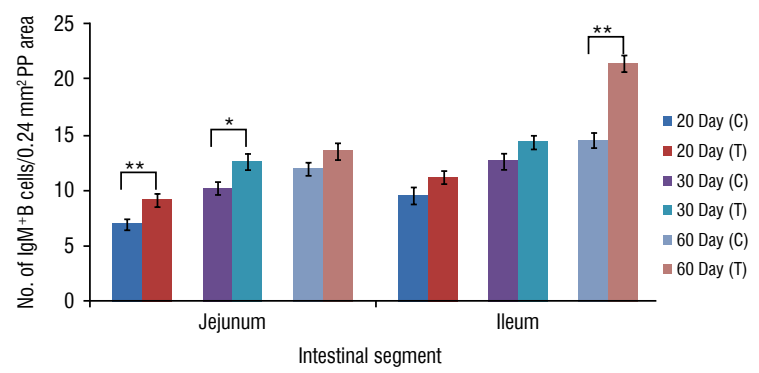

Figure 5. Localisation of $B$ lymphocytes in the small intestine of control and treatment group of piglets $\left({ }^{*} p<0.05,{ }^{* *} p<0.01\right) ; A, B$. $\lg A^{+}$ B lymphocytes in lamina propria (LP) and Peyer's patch (PP) area; C, D. $\operatorname{lgM}^{+}$B lymphocytes in LP and PP area.

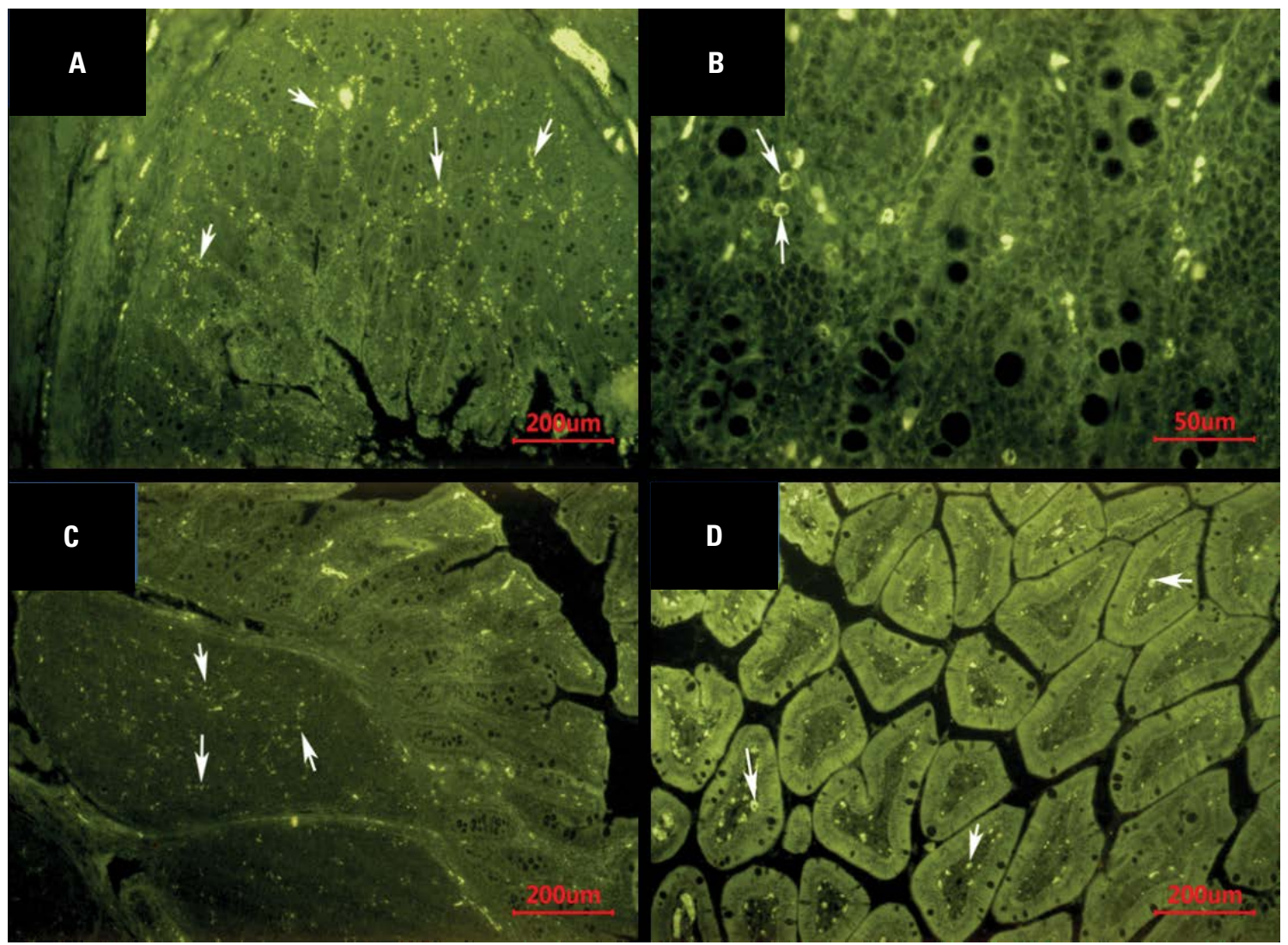

Figure 6. Ig $\mathrm{M}^{+} \mathrm{B}$ lymphocytes in treated piglets; A. Predominant location in the crypt area (arrow) of 60-day-old jejunum (Indirect-IF method, $\times 100$ ): B. Crypt area (arrow) in 60-day-old duodenum (Indirect-IF method, $\times 400$ ); C. Peyer's patch (PP) area (arrow) in 30-day-old ileum; D. Core of the villi (arrow) in 30-day-old jejunum (Indirect-IF method, $\times 100$ ). 
mucosa in both the groups. Moreover, their presence was also revealed in the PP area of jejunum and ileum (Fig. 3D). The total number of $\mathrm{CD} 8^{+}$cells in the current study showed an elevated pattern as per the age advancement in both groups. In the LP area, the number of $\mathrm{CD} 8^{+}$cells significantly increased at day 20 $(p<0.01)$ and day $30(p<0.05)$ in the duodenum; at day $20(p<0.05)$ and day $30(p<0.05)$ in the jejunum; and at day $20(p<0.01)$ in the ileum of the treatment group of piglets (Fig. $2 \mathrm{C}$ ). Similarly, in the PP area of treated piglets, their number increased significantly at day $20(p<0.01)$ and day $30(p<0.05)$ in the jejunum and, day $20(p<0.01)$, day $30(p<0.05)$ and day $60(p<0.05)$ in the ileum (Fig. 2D).

\section{$\lg \mathrm{A}^{+}$lymphocytes}

IgA expressing plasma cells were predominantly found in the LP of the crypts (Fig. 4A) irrespective of group and age. However, their presence was also observed in the cores of the villi (Fig. 4B) and the PP area (Fig. 4C). Some of the $\lg \mathrm{A}^{+}$cells were also observed in the epithelium along with their secretion in the LP area (Fig. 4D) of treated piglets. In all experimental animals, the largest populations of these immunoglobulin containing cells were found in the duodenum, followed by jejunum and ileum in the LP area. However, these counts were more in the ileum than jejunum in the PP area of this study. The total number of $\lg \mathrm{A}^{+}$cells was increased with the advancement of age in both the control and treatment groups of piglets under study. In the LP area, the mean number of $\lg \mathrm{A}^{+}$cells was significantly increased $(p<0.01)$ in all age-groups of the duodenum and significantly higher $(p<0.05)$ at day 20 of jejunum in the treatment group of piglets than in the control group (Fig. 5A). Similarly, in the PP area of the present study, these immunopositive cells were increased significantly $(p<0.05)$ at day 20 and day 30 in the jejunum and day 20 in the ileum (Fig. 5B). Furthermore, dietary inclusion of probiotic and zinc showed significantly higher $(p<0.01) \lg \mathrm{A}^{+}$cells at the PP area of day 60 in jejunum and ileum (Fig. 4C).

\section{IgM $\mathrm{M}^{+}$lymphocytes}

The $\lg \mathrm{M}^{+}$containing cells were predominantly located in the LP region of the crypt area (Fig. 6A, B) followed by the PP area (Fig. $6 \mathrm{C}$ ) and the core of the villi (Fig. 6D) irrespective of group and age. The $\mathrm{IgM}^{+}$cells were increased as per the advancement of age in both groups. The number of these cells varied depending upon segments of the small intestine and age-groups in the LP area. However, in the PP area, they were more predominantly located in the ileum than jejunum irrespective of group and age. In the LP area of the current study, the mean number of $\operatorname{lgM}^{+}$ cells was significantly increased $(p<0.01)$ in the treatment group of piglets irrespective of segments of the small intestine (Fig. 5C). Furthermore, in the PP area, these cells were significantly higher $(p<0.01)$ in the treated piglets at day 20 of jejunum and day 60 of the ileum (Fig. 6D). In addition, in the treated piglets, they were increased significantly $(p<0.05)$ at day 30 of the jejunum (Fig. 6D).

\section{DISCUSSION}

In the present investigation, the $\mathrm{CD} 4^{+} \mathrm{T}$ lymphocytes were mainly concentrated in the crypt area followed by the PP area (jejunum and ileum) and the core of the villus. The number of these cells was higher in piglets fed with probiotic and zinc than in the control group of piglets. In one of the previous studies, it was reported that the $\mathrm{CD}^{+}{ }^{+} \mathrm{T}$ cells were mainly located in the lamina propria and played a central role in regulating the immune system [6]. From the present findings, it could be concluded that the probiotic and zinc might be the main influencing factor for the changes of $\mathrm{CD}^{+} \mathrm{T}$ cells. Increased $\mathrm{CD} 4^{+} \mathrm{T}$ cells in the treatment group could modulate the production and secretion of secretory $\lg \mathrm{A}$ (SIgA) by secreting cytokines [3] and provide better and effective immunity to this group of piglets. The total number of $\mathrm{CD}^{+}$cells in the current study was higher in the treated group of piglets in all the segments of the small intestine. The higher number of $\mathrm{CD}^{+}$subpopulations present in the treatment group piglets might enhance defence against pathogens by cytotoxic $\mathrm{CD} 8^{+}$cells or maintenance and enhancement of the epithelial integrity by $\gamma \delta \mathrm{CD}^{+}$cells [7]. As per a previous study conducted by Galina et al. [8] probiotics have been found to increase $(p<0.05)$ the number of intraepithelial lymphocytes and the density of $\mathrm{CD}^{+}$cells in Peyer's patches and lamina propria. The CD19 marker assists the expression of all B lineage cells [23] and a study proved that the supplementation of zinc showed a higher percentage of CD19+ lymphocytes in human [11]. However, analysis of the $\mathrm{CD}^{+}$and $\mathrm{CD} 19^{+}$lymphocytes was not performed in the present investigation.

In the present study, IgA expressing plasma cells were predominantly found in the LP of the crypts, irrespective of group and age. In addition, some of the 
$\lg \mathrm{A}^{+}$cells were also observed in the epithelium along with their secretion in the LP area of treated piglets. In agreement with our findings, the other authors reported more populations of these immunoglobulin containing cells in the LP area of the duodenum, followed by jejunum and ileum [2]. However, these counts were more in the ileum than jejunum in the PP area of this current study. The mean number of Ig $\mathrm{A}^{+}$cells was higher in the treatment group of piglets compared to control animals in all segments of the small intestine. The highly significant increase of $\lg \mathrm{A}^{+}$ cells of the duodenum in all age-groups of treated piglets might be correlated with more immunoglobulin-producing cells in the duodenum, which might ensure a fast reaction to potential pathogens [6]. The secretory IgA of gut mucosa was an antibody isotype specialised in mucosal protection that played an essential role as the first line of defence and aided in regulating bacteria-host interaction [16]. The antigen uptake of probiotic bacteria in the treatment group of piglets of the present study could be carried out by $M$ cells or might be sampled by dendritic cells. Furthermore, the microenvironment cytokines would favour the clonal expansion of IgA B lymphocytes, increasing the number of IgA-producing cells and their passage to plasmatic cells in the different intestinal tissue of the gut. The higher number of $\lg \mathrm{A}^{+}$cells present in the treatment group could be concluded with better mucosal protection by boosting the immune system. In the current study, the number of $\operatorname{lgM}^{+}$cells was found to be more in the PP area as compared to $\lg \mathrm{A}^{+}$cells, which was correlated with the findings of the previous study in pigs [2]. The more number of $\operatorname{lgM}^{+}$cells in the PP area observed in the present study might be indicated that IgM was the first antibody to appear in response to initial exposure to an antigen [1]. In the present observation, the mean number of $\operatorname{lgM}^{+}$cells was higher in treated piglets irrespective of segments of the small intestine. In the previous study, it was documented that IgM bound to the polyimmunoglobulin receptor, which was an Fc receptor that facilitated the transcytosis of the soluble polymeric isoforms of IgA [13]. Polyimmunoglobulin receptor were mainly located on the epithelial lining of mucosal surfaces of the gastrointestinal tract. In this way, the IgM reached the mucosal surface and enhanced mucosal immunity. In the treatment group of the present study, an increased number of $\lg \mathrm{A}^{+}$ cells provided the environment to bind with $\operatorname{lgM}^{+}$ cells by the plgR and transported the $\operatorname{lgM}^{+}$cells to the apical mucosal epithelial cell surface. This might lead to better mucosal immunity in the treatment group of piglets.

\section{CONCLUSIONS}

The findings of the present study indicate that dietary supplementation of probiotic and zinc positively affected immune response in piglets that might help in promoting intestinal health, and improving piglet growth in pre and post-weaned period of life.

\section{Conflict of interest: None declared}

\section{REFERENCES}

1. Alberts B, Johnson A, Lewis J. Molecular Biology of the Cell. 4th ed. Garland Science, New York, UK 2002.

2. Allen WD, Porter P. The relative distribution of IgM and IgA cells in intestinal mucosa and lymphoid tissues of the young unweaned pig and their significance in ontogenesis of secretory immunity. Immunol. 1973; 24(3): 493-501.

3. Blum $S$, Alvarez $S$, Haller $D$, et al. Interactions between commensal bacteria and mucosal immunocompetent cells. Int Dairy J. 1999; 9(1): 63-68, doi: 10.1016/s09586946(99)00045-x.

4. Case CL, Carlson MS. Effect of feeding organic and inorganic sources of additional zinc on growth performance and zinc balance in nursery pigs. J Anim Sci. 2002; 80(7): 1917-1924, doi: 10.2527/2002.8071917x, indexed in Pubmed: 12162660.

5. Castillo M, Martín-Orúe SM, Taylor-Pickard JA, et al. Use of mannanoligosaccharides and zinc chelate as growth promoters and diarrhea preventative in weaning pigs: Effects on microbiota and gut function. J Anim Sci. 2008; 86(1): 94-101, doi: 10.2527/jas.2005-686, indexed in Pubmed: 17911238.

6. Che $C$, Pang $X$, Hua $X$, et al. Effects of human fecal flora on intestinal morphology and mucosal immunity in human flora-associated piglet. Scand J Immunol. 2009; 69(3): 223-233, doi: 10.1111/j.1365-3083.2008.02211.x, indexed in Pubmed: 19281534.

7. Chen $Y$, Chou K, Fuchs E, et al. Protection of the intestinal mucosa by intraepithelial gamma delta $T$ cells. Proc Natl Acad Sci U S A. 2002; 99(22): 14338-14343, doi: 10.1073/pnas.212290499, indexed in Pubmed: 12376619.

8. Gālina D, Ansonska L, Valdovska A. Effect of probiotics and herbal products on intestinal histomorphological and immunological development in piglets. Vet Med Int. 2020; 2020: 3461768, doi: 10.1155/2020/3461768, indexed in Pubmed: 32373310.

9. Gaskins HR, Kelly KW. Immunology and neonatal mortality. In: Varley MA (editor). The Neonatal Pig Development and Survival. CAB International, Wallingford, UK 1995.

10. Gill HS, Rutherfurd KJ, Prasad J, et al. Enhancement of natural and acquired immunity by Lactobacillus rhamnosus (HN001), Lactobacillus acidophilus (HN017) and Bifidobacterium lactis (HN019). Br J Nutr. 2000; 83(2): 167-176, doi: 10.1017/s0007114500000210, indexed in Pubmed: 10743496. 
11. Guo $\mathrm{CH}$, Wang $\mathrm{CL}$. Effects of zinc supplementation on plasma copper/zinc ratios, oxidative stress, and immunological status in hemodialysis patients. Int J Med Sci. 2013; 10(1): 79-89, doi: 10.7150/ijms.5291, indexed in Pubmed: 23289009.

12. Habel RE. Guide to the dissection of domestic ruminants. Michigan, Edwards Brother Inc. Ann Arbor, USA 1964.

13. Johansen FE, Braathen R, Brandtzaeg P. Role of J chain in secretory immunoglobulin formation. Scand $\mathrm{J} \mathrm{Im-}$ munol. 2000; 52(3): 240-248, doi: 10.1046/j.13653083.2000.00790.x, indexed in Pubmed: 10972899.

14. Kalita A, Talukdar M, Sarma K, et al. Small intestinal mucosal cells in piglets fed with probiotic and zinc: a qualitative and quantitative microanatomical study. Folia Morphol. 2021; 80(3): 605-617, doi: 10.5603/FM.a2020.0091, indexed in Pubmed: 32789842.

15. Lallès JP, Bosi P, Smidt $H$, et al. Weaning - a challenge to gut physiologists. Livestock Sci. 2007; 108(1-3): 82-93, doi: 10.1016/j.livsci.2007.01.091.

16. Lemme-Dumit JM, Polti MA, Perdigón G, et al. Probiotic bacteria cell walls stimulate the activity of the intestinal epithelial cells and macrophage functionality. Benef Microbes. 2018; 9(1): 153-164, doi: 10.3920/BM2016.0220, indexed in Pubmed: 29124968.

17. Liu H, Zhang J, Zhang S, et al. Oral administration of Lactobacillus fermentum 15007 favors intestinal development and alters the intestinal microbiota in formula-fed piglets. J Agric Food Chem. 2014; 62(4): 860-866, doi: 10.1021/ jf403288r, indexed in Pubmed: 24404892.
18. Mainau E, Temple D, Manteca X. Pre-weaning mortality in piglets. University of Barcelona, USA: Farm Animal Welfare Education Centre (FAWEC); No11/January 2015.

19. National Research Council (NRC). Nutrient requirements of swine. In: Computer model program for predicting nutrient requirements. 10th ed. National Academy of Sciences, Washington DC, USA. 1998.

20. Reid G, Jass J, Sebulsky MT, et al. Potential uses of probiotics in clinical practice. Clin Microbiol Rev. 2003; 16(4): 658-672, doi: 10.1128/CMR.16.4.658-672.2003, indexed in Pubmed: 14557292.

21. Sargeant HR, McDowall KJ, Miller HM, et al. Dietary zinc oxide affects the expression of genes associated with inflammation: Transcriptome analysis in piglets challenged with ETEC K88. Vet Immunol Immunopathol. 2010; 137(1-2): 120-129, doi: 10.1016/j.vetimm.2010.05.001, indexed in Pubmed: 20605641.

22. Scharek L, Altherr BJ, Tölke $C$, et al. Influence of the probiotic Bacillus cereus var. toyoi on the intestinal immunity of piglets. Vet Immunol Immunopathol. 2007; 120(3-4): 136-147, doi: 10.1016/j.vetimm.2007.07.015, indexed in Pubmed: 17870185.

23. Scheuermann RH, Racila E. CD19 antigen in leukemia and lymphoma diagnosis and immunotherapy. Leuk Lymphoma. 1995; 18(5-6): 385-397, doi: 10.3109/10428199509059636, indexed in Pubmed: 8528044.

24. Sozmen M, Brown PJ, Cripps PJ. IgA, IgG and IgM immunohistochemical staining in dormal dog salivary glands and in cases of chronic sialoadenitis. Vet Res. 1996; 27: 285-294, indexed in Pubmed: 8767890. 